\title{
Criminological and Legal Investigation of Independence and Despotism of the Judge in Judgment
}

\author{
Gholam-reza Mahdavi ${ }^{1}$ \\ ${ }^{1}$ Department of Law, College of Human Science, Saveh Branch, Islamic Azad University of Saveh, Iran \\ Correspondence: Gholam-reza Mahdavi, Department of Law, College of Human Science, Saveh Branch, Islamic \\ Azad University of Saveh, Iran. E-mail: gholamrezamahdavi3016001@gmail.com
}

\author{
Received: July 9, 2016 Accepted: October 19, 2016 Online Published: November 30, 2016 \\ doi:10.5539/jpl.v9n10p103 URL: http://dx.doi.org/10.5539/jpl.v9n10p103
}

\begin{abstract}
The most important criteria for realization of justice are independence and impartiality of judge when he makes a decision; it means that judge must see himself in a situation that he is not afraid of anything, and he should consider merely God, law and conscience in decision-making. Judge must have many conditions to sit in this position, and the judgment is perhaps the only position that he must has all these conditions together. The most basic tool of an independent judge is his knowledge and justice, and when knowledge and justice place beside an independent character, judicial process will be complete. In the Iranian constitution it has been reflected in Articles 156, 164 and 170 which show judge's independence. But beside independence, despotism of judge in decision-making should be noted. Despite basic difference between two words of "independence" and "despotism", there is also a tiny likeness that both of the words have same meaning of making decision without involvement of other's comment, but the root and origin of each word is different. Also it should be emphasized that consulting have not any conflict with independence of judge, but according to the advice of Sharia in verses and traditions of Islam, consultation is necessary for intellectual enhancement and development of people, especially the judge, who determines dignity, life, property and honor of people by his decision and his independence may convert into despotism and arrogance, without consulting. Constitution and normal laws have consider some solutions in various principles and articles to prevent despotism and to protect independence of judge in Iranian law that this issue can lead to a fair judicial system in Iran.
\end{abstract}

Keywords: judge, independence, despotism, verdict

\section{Introduction}

Independence means going to a high place, being self-bailiff, doing a work by own without involvement of other people (Moein, 2004). Since it is apparent from meaning of the word "independence", it refers to someone who does a work, performs it without imposing other's comment, willingly, with freedom of thought, and by his own authorization and volition that this concept refers to the principle of intellectual independence and volition, and the existence of this concept which is required to implement justice and security of society, is necessary in case of judges and it is not subject to any discretionary, because there is no expediency over the truth, and also this justice never comes into effect except by someone who implement it by intellectual independence and without intellectual imposing by others. Despite sentencing by judge is a scientific action, but finding the principles, interpreting them and their compliance with the topic of verdict is deemed as a discretion originally which is along with intellectual understanding, and this understanding is specific for the judge who issues verdict and expresses freely and independently his thought, not his own comment, and thereby, independence of judge is considered as fundamental pillar of judicial authorities and all of affairs are servicing this process, and any assessment about the performance of jurisdictions will be done based on verdicts which are according to justice and whose base is independence of judge.

But, independence without guarantee to enforce justice, is dangerous and transforms to despotism. It will be discussed in the next chapter in details and for these reason, justice and knowledge are of fundamental conditions of judgment.

In a way that Imam Ali (AS) said Malek Ashtar the conditions of judge:

Malek! People are consisting of various opposite groups which one of the groups are righteous judges. You select 
best of the people for judgment, those who:

1) frequent references would not put them in pinch;

2) clash of opponents with each other would not make him angry;

3) would not insist on mistakes;

4) returning to the truth would not be hard after being clear for him;

5) lay off greed out of their hearts and would not be satisfied by little research;

6) is more cautious than others in doubts;

7) is more insistent than others in searching for reasons and proofs;

8) would be lees tired by frequent references of complainants;

9) is the most comprehensive people in terms of knowledge, patience, and piety;

10) would not be affected by situations;

11 ) is patience in exploring of issues;

12 ) is the most decisive in resolving of conflicts after clearance of truth;

13) would not be deceived by great admiration.

These conditions has been summarized in jurisprudential books of Shia in the titles such as full wisdom, maturity, faith, justice, purity, knowledge and discretion.

Thus, judgment is perhaps the only position that he must has all these conditions together. The most basic tool of an independent judge is his knowledge and justice, and when knowledge and justice place beside an independent character, judicial process will be complete. For this reason, if judge acts for judgment without these two conditions, and merely by having independency, an unfair and non-wisely willingness and understanding will be created and its consequence will not be anything but oppression to the society.

\section{Main Text}

\subsection{Independency of Judge from the Viewpoint of Constitution}

According to Article 156 of constitution, judiciary branch is an independent entity which is supportive for individual and social rights of people, and is responsible for realization of justice, the Article expresses some tasks in five paragraph which originally says the health of judgment is subject to independence of judge and his independence is subject to providing of factors of independency from which job security is one of the main factors that has regulated in Article 164 of constitution.

"A judge cannot be removed, whether temporarily or permanently, from the post he occupies except by trial and proof of his guilt, or in consequence of a violation entailing his dismissal. A judge cannot be transferred or re-designated without his consent, except in cases when the interest of society necessitates it, that too, with the decision of the head of judiciary branch after consultation with the chief of the Supreme Court and the Prosecutor General. The periodic transfer and rotation of judges will be in accordance with general regulations to be laid down by law."

Another reason for independency of judge is Article 170 of Constitution which prevents him to execute governmental ratifications and byelaws which are opposite to Islamic rules and regulations.

\subsection{Article 170 of Constitution}

"Judges of courts are obliged to refrain from executing statutes and regulations of the government that are in conflict with the laws or the norms of Islam, or lie outside the competence of the executive power. Everyone has the right to demand the annulment of any such regulation from the Court of Administrative Justice."

In this way and by the help of these two Article, it can be seen that even head of the judiciary branch cannot remove by administrative and executive decisions, or even cannot transfer them without their interest, while in executive branch, head of executive branch can remove or transfer employees of his subsidiary, from a supreme authority of a ministry to a low-level employee, by administrative decisions or based on administrative requirements, and change or shift in head of executive branch or a minister may result in thousands of removals and installations, while in judicial branch, change in head of judiciary branch will not have any role in change or shift in judges.

But, the most important issue about the independence, is immunity of judge in his performance, in a way that 
judge can brought anyone to court due to the charge against him, and can condemn him by short but documented and reasonable terms; height of peaks of power and wealth in society don't play any role in his decision-making, and if necessary, he only think to conquer those peaks not to the height of them, and he does not see anyone above himself but God and his conscience.

\section{Judgment Is a Position or a Job?}

According to numerous verses and traditions, and also rational reasons, judgment is a position not a job. God says in Holy Quran: "O David! Surely we have made you a ruler in the land; so judge between men with justice and do not follow desire."

This verse expresses that judge because of adjudicate and judgment, is considered as successor of God and originally, judgment is the right of almighty God and judge has undertaken this situation on behalf of God, because, Prophet David, in addition to being prophet, was an Imam and judge on behalf of God.

\subsection{Position of Judgment from Standpoint of Nahj al-Balagha}

Imam Ali (AS) says in his famous sentence to Judge Shuraih: "You are placed in a standing where is the place of prophet and successor, or the place of wretch people." Imam Ali (AS) wanted to show criticality of judgment and teaches us that righteous and fully qualified judges, are placed in the position of prophet and successor. Dignity and greatness of judge is equal to the dignity of governor and ruler, and judgment is of supreme divine positions which has resigned to the Prophet Mohammad by God, and Prophet Mohammad has given it over Imam Ali (AS) and infallible Imams, and they to fully qualified scholars; a position which cannot be realized except by governance, and it is of the main dignities of guardianship (Walayah) and it is much enough associated with the government so that it seems they are one.

\subsection{Independence of Judge as Protector of Judicial Health and Security of Society}

The most important criteria for realization of justice are independence and impartiality of judge when he makes a decision; it means that judge must see himself in a situation that he is not afraid of anything, and he should consider merely God, law and conscience in decision-making. As a consequence, people will feel peace and security when they recourse him willingly, without being worry and with confidence in his judicial independence. Also the judicial authority will be a secure place to execute actual justice, and will be an awning for people. But unacceptability of jurisdiction's work in the viewpoint of people in terms of judicial dependency is an alarm that gradually results in lack of confidence in judicial system and judges so that people attempt to find a middleman who firstly recommends the judge, and then they go to the court. Furthermore, it is needed that intellectual stream and voice of justice draw serious attentions by effort for independency and impartiality of judge, so judicial health and security of society can be ensured. Fair judicial security in execution of clause 14, Article 3 of constitution $^{1}$ for all of people is one of duties of Islamic Governance that judicial system as a part of Islamic society's government is responsible for this serious task.

\subsection{Independency as a Support for Immunity of Judges}

The principle of immunity of judges is a rational and reasonable issue because if judges have not immunity, fair fulfilling of duty will be very difficult and even impossible; this immunity will not be created except by development of independency for judges, because judges as the main guards of justice, freedom, and restoring rights of people, are forced to have independency, security and peace of mind against gold and force owners and their influence and requests, and they should not be worried about change of position and relegation of judicial rank, otherwise no immunity will be imaginable for them.

\section{Effective Factors on Independency of Judge from Standpoint of Nahj al-Balagha}

A) Judge's livelihood

Imam Ali (AS) said Malek Ashtar: “Attempt more than ever to investigate your judge's judgments, and spread tablecloths of generosity in giveaway to him, so that his demands is removed and he does not have any needs and requirements from people." (Nahj al-Balagha, Sermon No. 34)

He also says Reqa'a, governor of Ahwaz: "Don't accept gifts and rewards from parties of conflict." (Nahj al-Balagha, Sermon No. 35)

He says elsewhere: "Any system needs judge, and the judge needs livelihood, and the livelihood must be provided by public treasury not by people." (Nahj al-Balagha, Sermon No. 37)

\footnotetext{
${ }^{1}$ Clause 14, Article 3 of constitution: securing the multifarious rights of all citizens, both women and men, and providing legal protection for all, as well as the equality of-all before the law.
} 
As it can be understood from the speech of his majesty, the nature of livelihood is rely on the need for keeping the life, judge must not be necessitous to bribe, reward and salary. This rational approach which is implementing in some countries by giving blank check to judges, is adapted from Imam Ali's lifestyle.

\section{B) Judgment's customs}

Customs referred to tips that judge by observing them in his behaviors and speeches within society and judgment meetings can reach a better context for fair judgment, in addition to retaining his character and dignity. The following customs can be understood from the collection of orders which Prophet Mohammad has given Imam Ali (AS), and his practical lifestyle, and advises which Imam Ali (AS) told judges and governors such as Malek Ashtar, Ahwaz's governor, Shuraih, the judge of Basrah, and Abol-Aswas Doeli, the judge of Kufah:

1) Observing full impartiality in judgment

2) Observing equity between parties of conflict in terms of looking, talking, sitting and paying attention.

\subsection{Difference between Independency in Decision and Despotism in Decision}

Despotism means 1) loneliness in judgment; 2) high-handedness; 3) willfulness; and 4) Oppression and aggression caused by overall independence. As it can be seen, despite basic difference between two words of "independence" and "despotism", there is also a tiny likeness that both of the words have same meaning of making decision without involvement of other's comment, but the root and origin of lonely judgment is different in each word. Freedom of willing and thought in case of independency of decision, has origin in rationality, logic, justice, and reform in affairs, but in case of despotism of decision it has origin in ignorance, arrogance, darkness, intellectual dictatorship and corruption in affairs, thus implementation of independency of decision without support of science and justice will have no consequence but despotism of decision.

\subsection{Junction of Forms of Judge's Independency and Despotism}

As it said already, despite there is a likeliness between independency and despotism which is lonely decision-making, but in case of independency it is supported by justice and relationality, but in case of despotism, it relied on darkness, ignorance and malice that human's passions turn him toward this side and prevent him to accept truth.

For example, consider a judge who is dealing with a judicial file. After initial investigations, he conclude that the accused should be condemned, ironically, in the meantime the accused had a bad behavior with the judge. This makes him more serious to make the decision, but after continuing investigations and provision of further reasons, innocence of the defendant is proven. In this situation, the judge reaches to ethical junction of humanity and sensuality. It is obvious that if he insist on his first decision, he has followed his sensuality and has committed despotism of decision, but if he follows his relationality, justice, and piety, and shows flexibility and intellectual freedom, and issues his acquittal, he has independency of decision.

\subsection{Objectivity of Judge's Independency in Sentencing}

As it was noted already, there are many reasons which proves that existence of independent judge is incidental for execution of justice and creation of judicial security in society, and this independency in position of sentencing and making judicial decisions is deemed kind of commenting which realizes and reaches to the point of objectivity.

Right-centered judge does not allow anybody to abuse his pride or abuse his ignorance. All of his actions is intended to promote the right, and he is proud of realization of right, and cancellation of wrong.

Right-centered judge is not afraid of anybody when investigating a file and sentencing by full independency, and considers even a carat in case of public treasure.

Judge is the only person who has the right to interpret laws to execute laws and differentiate the right according to the clear wording of Article 73 of constitution ${ }^{2}$. Or only executer of law who can issue verdict of the case referring to valid Islamic resources of authentic Fatwa if there is no appropriate law in codified laws ${ }^{3}$.

As a result of independency of judge, his diagnosis and decision-making reaches its climax point in the context

\footnotetext{
${ }^{2}$ Article 73 of constitution: The interpretation of ordinary laws falls within the competence of the Islamic Consultative Assembly. The intent of this Article does not prevent the interpretations that judges may make in the course of cassation.

${ }^{3}$ Article 167 of constitution: The judge is bound to endeavor to judge each case on the basis of the codified law. In case of the absence of any such law, he has to deliver his judgment on the basis of authoritative Islamic sources and authentic fatwa. He, on the pretext of the silence of or deficiency of law in the matter, or its brevity or contradictory nature, cannot refrain from admitting and examining cases and delivering his judgment.
} 
of verdict freely, and based on conscience and law.

For this reason, the purpose of judicial independency is that judge should not consider illegal and illegitimate orders, comments, and requests in sentencing and should not be afraid of missing his occupation or position, and change in location of working place and job position, otherwise, stature of justice will be bent and broken and there will not be independency in decision, but despotism in decision will be replaced with.

\subsection{Does Consulting of a Judge Is Incompatible with Judicial Independency?}

Considering that the feature of consultation is based on being optional, not mandatory, finally it is the consulter that makes decision without any impose by counselor, so consulting has no contradiction with independency of judge in decision, but according to the advice of Sharia in verses and traditions of Islam, consultation is necessary for intellectual enhancement and development of people, especially the judge, who determines dignity, life, property and honor of people by his decision and his independence may convert into despotism and arrogance, without the consulting. For this reason, consulting is an approved and acceptable in any culture which results in making the best decisions and prevents to get into abyss of heavy mistakes and consequently failure.

Imam Ali (AS) says: "Despotism in decision and not consulting are adjectives of ignorant man, and it is only ignorant man who loves his own comment."

Or says elsewhere: “whose comment is better who doesn't consider himself needles from comment of counselor."

Finally, we conclude that consulting not only has no conflict with independency of judge, but also it is same as agreement, and its opposite point is "not consulting" which results in despotism in decision, and everyone who works solitary, would be perished.

\subsection{Independency of Judge; Absolute or Relative?}

Considering that rules of our country are codified and adopted by Islamic Council Parliament, and on the other hand, judges are permitted and appointed as judge. Therefore, it is obvious that in terms of the duty of law execution -specially in case of formal laws- his independency cannot be absolute, but it is a relative issue, and even Mujtahid judges cannot verdict against adopted laws, even though they know this law against Sharia, in a way that in execution of clause of Article 3 of the Civil Procedure Code ${ }^{4}$ if he knows the law against Sharia, and in the other words, he finds the law againt his jurisprudential comments, without having the right for sentencing against adopted law, the file will be referred to another branch in order to be examined, as a result the sentenced verdict will be according to this codified law and nothing but.

By this explanation, everyone who is appointed on behalf of the governance, is a permitted and appointed judge, however, this person is a Mujtahid or non-Mujtahid, because the governance has appointed him in judgment position conditionally, and also has permitted him conditionally to judge in the context of laws which has determined by the governance, and he cannot exceed the context. Furthermore, both Mujtahid or non-Mujtahid judges miss their full independence in case of being permitted and appointed on behalf of governance, and will be limited and districted in context of the law which is determined by governance, only with the difference that in cases where there is no positive and codified law to sentence a verdict in those cases, non-Mujtahid judge should sentence according to Article 167 of constitution according to fatwas of other prestigious and authentic scholars, but Mujtahid judge should sentence according to his own fatwa and comment, and decide the case.

Thus, as all of judges in Islamic Republic of Iran are permitted and appointed, furthermore, their independency not only is full and absolute, but also is limited and districted in the context of positive laws. This means that judge examines and sentences claimed cases according to any regulation which is posed, codified and given the judge by the governance.

But in terms of interpretation of codified law in execution of Article 73 of constitution ${ }^{5}$, judge is fully independence according to his legal recognition and understanding, and nobody could prevent him to recognize and could not impose his comment, as a result, they are independence in the context of positive laws, against governance, authority, senior judicial officers, and some persons who are authorized in case of salaries, appointment and dismissal, and promotion of judges, and also agains any authority and official, and nobody could ask him about the verdict that he has sentenced, or issue an order and impose his comment, even Disciplinary Court of Judges which is responsible for judgment about judges could not also interpellate or ask a

\footnotetext{
${ }^{4}$ If judge is Mujtahid and finds law against Sharia, file will be referred to another branch in order to be examined.

${ }^{5}$ Article 73 of constitution: "The interpretation of ordinary laws falls within the competence of the Islamic Consultative Assembly. The intent of this Article does not prevent the interpretations that judges may make in the course of cassation.
} 
judge because judicial commenting.

According to aforesaid reasons, judge has full independency in case of judicial commenting, so that constitutional laws of claims have recognized it and do not permit anyone to interfere, but it is the judge person who must be equipped with science, justice and piety to prevent transformation of independency in decision to despotism, because judicial independency is incidental of execution of justice, and having science and justice are incidentals of that independency, in a way that having justice and competency are of conditions of judge according to Sharia, and also according to clause 3, Article 158 of constitution of Islamic Republic of Iran . Furthermore, it is the judge who act judicial commenting and sentence verdict and executes law fairly by having strong support of required science and justice, without any love and hatred, and without following sensuality, because sentencing is a deduction and internal issue, and will not be controllable if the judge person has not the required science and justice, and it seems to be an invisible action and nobody except God could read intentions of humans. God says Prophet David in Holy Quran: “... so judge between men with justice and do not follow desire." This means that judge's task is judgment between people, not over people which reveals a type of authoritarian governance, and if so, he has followed sensuality, but if he lives between people and does not consider himself higher than them, he will not comment arbitrarily and will not follow sensuality, so he will not exceed circle of justice, this is the time that he executes justice with full independence.

Furthermore, beside the principle of judge's independency, there are principles of justice, piety, and defiance to wealth and not having even smallest greed to properties of world that are fundamental conditions which prevent and control him. All of judicial principles and conditions are same this, and are linked together like a chain, and all of them should be considered overall. In judicial system of Islam, conditions of judge must be considered balancedly and mutually, and the condition of judge's independency has been considered beside conditions of Ijtihad, profession and skill in judicial and legal sciences, justice, piety, self-esteem and spiritual asceticism. Thus if judge has shortage in justice or piety and has absolute power, such a great danger will threat people's prestige, rights, life, and property, and in this situation, judicial independency will transform to judicial despotism.

\subsection{Barriers to Judge's Despotism in Decision from the Viewpoint of Laws}

\section{a) Constitution}

Constitution of Islamic Republic of Iran which is derived from the shining Sharia of Islam, has placed barristers to despotism in decision in line with independency of judge in decision in various articles and has obliged him to examine and sentence raised claims in the area of codified laws.

1) Article 166 of constitution: "The verdicts of courts must be well reasoned out and documented with reference to the articles and principles of the law in accordance with which they are delivered."

it can be seen that reasoning by demonstrative reasons of lawsuit and citation to articles of civil and penal codes are of tasks of judge when sentencing, so the judge cannot sentence without reasoning and citation to demonstrative reasons in which case, the sentenced verdict is against Sharia and constitution, and consequently it should be cancelled and is not executable.

2) Article 166 of constitution: "The judge is bound to endeavor to judge each case on the basis of the codified law. In case of the absence of any such law, he has to deliver his judgment on the basis of authoritative Islamic sources and authentic fatwa. He, on the pretext of the silence of or deficiency of law in the matter, or its brevity or contradictory nature, cannot refrain from admitting and examining cases and delivering his judgment."

According to this article, judge is obliged to find verdict of each case firstly in codified laws, otherwise he cannot sentence based on his own comment and desire which is kind of high-handedness and despotism in decision, but also in this situation he must sentence appropriate verdict according to authoritative Islamic sources and authentic fatwa which is deemed as substitute law that is prescribed by constitution, and even cannot refrain from admitting and examining on the pretext of silence of or deficiency of law in the matter, or its brevity or contradictory nature. Originally judge is not permitted to act authoritarily.

\footnotetext{
${ }^{6}$ Article 158 of constitution: "The head of the judiciary branch is responsible for the following:

1) Establishment of the organizational structure necessary for the administration of justice commensurate with the responsibilities mentioned under Article 156.

2) Drafting judiciary bills appropriate for the Islamic Republic.

3) Employment of just and worthy judges, their dismissal, appointment, transfer, assignment to particular duties, promotions, and carrying out similar administrative duties, in accordance with the law.
} 
3) Article 171 of constitution: "Whenever an individual suffers moral or material loss as the result of a default or error of the judge with respect to the subject matter of a case or the verdict delivered, or the application of a rule in a particular case, the defaulting judge must stand surety for the reparation of that loss in accordance with the Islamic criteria, if it be a case of default. Otherwise, losses will be compensated for by the State. In all such cases, the repute and good standing of the accused will be restored."

According to this article, in case of judge fault which means reckless and negligence, the judge is responsible and guarantor for compensation for material and moral damages to the person who is affected by the verdict, but at the same time it does not mean restrictions on judge's authority, but means prevention of judge's despotism and acting authoritarily.

4) Article 170 of constitution: "Judges of courts are obliged to refrain from executing statutes and regulations of the government that are in conflict with the laws or the norms of Islam, or lie outside the competence of, the executive power. Everyone has the right to demand the annulment of any such regulation from the Court of Administrative Justice."

According to that any ratifications and byelaws which are opposite to laws and Islamic rules, or out of authority limit of executive branch, are kind of imposing comment, furthermore, any judge who execute them, originally has exceed the area of codified law, so this article prevents judges to execute these type of ratifications.

5) Article 36 of constitution: "A sentence to punishment and its execution must only be by the decision of a competent court, and by virtue of law."

This article reveals observance of the principle of legality of criminal punishment which is derived from the verse in which God says: "nor do We chastise until We raise an apostle."

Or it is in accordance with the rule of "No punishment except in accordance with the law". As a results, firstly no authority even competent judicial authority has the right to condemn anybody unless a punishment has been determined already for his action. Secondly, this criminal action must be proven in competent court. Both of these cases indicate prevention of despotism and willfully of judge.

b) Normal laws

1) Article 3 of the Civil Procedure Code: "Judges are obliged to judge claims on the basis of laws, sentence appropriate verdict of finalize the conflict. If statute laws are not complete or clear, or are inconsistent, or there is no law in case of raised matter, they must judge on the basis of authoritative Islamic sources and authentic fatwa and legal principles which are not Contrary to Sharia, and they cannot refrain from examining and sentencing the cases on the pretext of the silence of or deficiency of law in the matter, or its brevity or contradictory nature, otherwise they have refused to Adjudicate the right and will be condemned to its punishment."

Clause: If judge is Mujtahid and finds law against Sharia, file will be referred to another branch in order to be examined.

In fact, this article reflects judge's independency, and also Article 147 of constitution. It should be noted in this regard that due to generality of courts in addressing civil conflicts between people, understandably the most varied affairs in all dignities of society are been raised there, and probably there is no specific law in case of some matters, and however, judge must address the claim according to the mentions duty in Article 147 of constitution.

Punishment subject to Article 3 of the Civil Procedure Code $^{7}$ has been predicted for refugees of judgment in Article 597 of Islamic Punishment Code which has considered criminal enforcement for judicial despotism of judge, meanwhile ensures independency of judge.

2) Article 8 of the Civil Procedure Code: "No official or governmental organization of authority could change verdict of court or prevent its execution, unless the court which has sentenced the verdic, or higher authority, only in cases which are determined in the law."

This article which says no official or governmental organization of authority could change verdict of court or prevent its execution, clearly reveals assurance of judge's independency in decision, and even the court which has sentenced the verdict cannot violate it, because otherwise it would be a kind of despotism in decision of

\footnotetext{
${ }^{7}$ Article 597 of Islamic Punishment Code: "Each of judicial authorities to which a complaint which is set up according legal conditions is presented, and despite addressing the case is of their duties, if they refuse to accept the complaint or to address them, or the delay sentencing against the law, or behave against the clear wording of law, on any excuse, although the pretext of silence of or deficiency of law, they will condemn to 6 month to year of expulsion of judicial careers for the first time, and permanent expulsion in case of repetition, and anyway will condemn to pay incurred losses."
} 
judge, the judge could change his verdict any time he wanted and could violate the right of claimant.

3) Article 283 of the Civil Procedure Code: "The court cannot force parties to take an oath without request of them, and if it forced them to swear, it would not be effective, and after that if anyone requested taking an oath, the oath must be repeated.

This article reveals that the judge has been prevented to catch a reason for both parties, and in other words, he is not fully permitted to perform any illegal action, but even in collecting the reasons he must act in the context of law and take oath in case of request of parties, otherwise the oath will not be effective.

So, according to what was said, independency of judges in decision-making is recognized and these decisions must be based on legal and religious reasons to prevent probable authoritary of judges which is the despotism in decision. Consequently, codified laws has determined some measures in order to prevent despotism in decision by judges and to enforcement to execute them as are described in the following:

1) Legality of crimes and punishments.

2) Reasonability and document-basis of verdicts of judicial authorities.

3) Existence of appeal process to protest court decisions

4) Observance of relational deadline for addressing the claims

5) The right to select advocate freely in order to ensure defensive rights of defendant

\subsection{Contexts of Barriers to Judicial Independency}

Laws have been noted in the previous section all indicate the action of legislator on the basis of The principle of impartiality of judges and their independency in judgment, and final goal of this action is to execute justice and judicial security in society, and it is obvious that justice which means putting everything on its own standing, will be realized when an efficient and reckless system is responsible for this task. The purpose of being reckless is that judicial branch has no consideration except legal considerations, and is not afraid off anybody -including private, public or governmental persons- to execution justice, otherwise people will feel peace and security.

It has been said that Churchill, popular first minister of UK who was famous in politics, in the midst of World War II, when his country was in a bad situation and hopes for improvement of country's situation and winning in the war has been reduced, asked his minister of justice that how is the status of courts and do people believe fairness of trial and satisfied with judicial system?

Lord Chancellor, Justice Minister of the time gave a positive response after several days of investigation. Churchill told him decisively that there is no concern, we will win the war.

This historical story indicates the significant importance of justice in increment of power and progress of country. The shining Sharia of Islam has considered numerous conditions for judge that their summary and abstract are justice, rationality, and reputation of judge. It needs the Inevitably the help of selecting entities in the process of judges recruitment, and the help and legalism of effective persons in judicial appointments, and it should be tried to not place the bridle of justice in hands of foolish persons in order to prevent damaging this eastern principle, because its negative results and consequences including dissatisfaction and lack of public trust in judicial system will be turn directly to the whole governing system.

The following issues can be a context of barriers to judicial independency of judges and finally result in fundamental damage on execution of justice in society:

1) Using extrajudicial and personal communications;

2) Prevalence of intermediation;

3) Governance of relation over regulation;

4) Relationship-based, ethnic, and tribal management instead of meritocracy;

5) Weakening of rule of law and degradation of law's credibility as a slogan;

6) Prevalence of influence on judges;

7) Violation of judge's dignity;

8) Leaping and unsystematic promotion of judges which results in flattery by them, so, obedience which is same as judicial dependency, will replace with merit and competency;

9) Intervention of higher judicial managers in judicial decision-making of judges; 
10) Weakness of judicial science and knowledge which leads to lack of self-confidence and consequently, lack of judicial independency; and

11) Politicization of judicial authorities.

Another issue which should be thought about it as a problem in judicial independency, is the matter of right of dismissal of judges or their relocation. This issue in Article 164 of constitution has been narrowed to the expediency, and expediency is effective in relocation, not in dismissal, but in relocation just one person decides and he is the head of judicial branch. There is the title of expediency, but what mechanism exists for discernment of expediency? Consultation has added beside expediency, but should this consultation be effective? Does non-considering of that consultation is reprimandable? Or discernment of expediency is merely the task of head of judicial branch? Anyway, all of cases of appointment, dismissal or relocation without reason and on the excuse of expediency results in deprivation of courage and independence of judge, and may foster him conservative and perhaps flattering, which are kind of judicial poison.

A judge how much can resist against external spaces which is created out of judging court and in the public thoughts? When some people write on walls that X must be executed, or Y must be free, or media blaze that $\mathrm{Z}$ is corruptor or enemy etc. before existence of trial, so, how can do the poor judge? Can he sentence based on his recognition, or should consider this heavy atmosphere? The atmosphere is not affected by him, and it will be more tragic when high-ranking officials of judicial system provoke this space, in this situation, independency of judge already been ruled out, it is in this step that expectations for fair and impartial sentencing becomes difficult Therefore, the solution is that much enough culture should be built so that these prejudgments will not be done. In the language of criminology it can be said that situational prevention must be performed to remove the context of these issues, and the judge could investigate the case and sentence willingly and with full intellectual independence.

"We believe that we are free in our opinions while we don't know that we are affected by factors and causes that none of them have invented by us and we are not aware of their status", Edmond Picard, famous French criminologist said.

In this way, if those declared cases will not be settled structurally, we should not expect full judicial independency which is required for execution of justice, and it seems that in the current conditions, judicial community of Iran is being infected more or less with big plague of lack of sufficient independency of judges, according to the aforesaid reasons, and it cannot be denied, and it should be tried much enough toward its correction.

\subsection{Materials and Methods}

It was tried in the current research to address the topic of independency and despotism of judge in decision-making using library studies, taking notes, and analyzing, and using articles of constitution (Articles 3, $73,153,156,158,164,166,167,170,171$, etc.) and also some articles of normal lwas such as Civil Code and Civil Procedure Code. Also, I the current study, some verses and traditions have been cited due to basing the rules and regulation on jurisprudence of Imamiyyah. By investigating those verses and traditions and also rules and regulation, the research has obtained some conclusion which will be noted in the next section.

\section{Conclusion}

The most important criteria for realization of justice are independence and impartiality of judge when he makes a decision; it means that judge must see himself in a situation that he is not afraid of anything, and he should consider merely God, law and conscience in decision-making. Despite the independence of judge which is required to implement justice and security of society, is not subject to any discretionary, because there is no expediency over the truth. It is apparent from meaning of the word "independence" that it refers to someone who does a work without imposing other's comment, willingly, with freedom of thought, and by his own authorization and volition that originally this concept refers to the principle of intellectual independence and volition, and justice will not be implemented unless by someone who implement it by intellectual independence and without imposing other's comment. The principle of immunity of judges is a rational and reasonable issue because if judges have not immunity, fair fulfilling of duty will be very difficult and even impossible; this immunity will not be created except by development of independency for judges, because judges as the main guards of justice, freedom, and restoring rights of people, are forced to have independency, security and peace of mind against gold and force owners and their influence and requests, and they should not be worried about change of position and relegation of judicial rank, otherwise no immunity will be imaginable for them.

Judge must have many conditions to sit in this position, and the judgment is perhaps the only position that he 
must has all these conditions together. The most basic tool of an independent judge is his knowledge and justice, and when knowledge and justice place beside an independent character, judicial process will be complete. For this reason, if judge acts for judgment without these two conditions, and merely by having independency, an unfair and non-wisely willingness and understanding will be created and its consequence will not be anything but oppression to the society. In the Iranian constitution it has been reflected in Articles 156, 164 and 170 which show judge's independence. But beside independence, despotism of judge in decision-making should be noted.

Despite basic difference between two words of "independence" and "despotism", there is also a tiny likeness that both of the words have same meaning of making decision without involvement of other's comment, but the root and origin of lonely judgment is different in each word. Freedom of willing and thought in case of independency of decision, has origin in rationality, logic, justice, and reform in affairs, but in case of despotism of decision it has origin in ignorance, arrogance, darkness, intellectual dictatorship and corruption in affairs, thus implementation of independency of decision without support of science and justice will have no consequence but despotism of decision.

But independency of judge is a relative affair, not an absolute issue. Considering that rules of our country are codified and adopted by Islamic Council Parliament, and on the other hand, judges are permitted and appointed as judge. Therefore, it is obvious that in terms of the duty of law execution -specially in case of formal laws- his independency cannot be absolute, but it is a relative issue, and even Mujtahid judges cannot verdict against adopted laws, even though they know this law against Sharia, in a way that in execution of clause of Article 3 of the Civil Procedure Code if he knows the law against Sharia, and in the other words, he finds the law againt his jurisprudential comments, without having the right for sentencing against adopted law, the file will be referred to another branch in order to be examined, as a result the sentenced verdict will be according to this codified law and nothing but.

Also it should be emphasized that consulting have not any conflict with independence of judge, but according to the advice of Sharia in verses and traditions of Islam, consultation is necessary for intellectual enhancement and development of people, especially the judge, who determines dignity, life, property and honor of people by his decision and his independence may convert into despotism and arrogance, without consulting. Constitution and normal laws have consider some solutions in various principles and articles to prevent despotism and to protect independence of judge in Iranian law that this issue can lead to a fair judicial system in Iran. Articles 166, 167, 170, and 171 of constitution, and also Articles 3, 8, and 283 of Civil Procedure Code are of cases which has placed barriers to despotism of judge in decision.

\section{References}

Al-Razi, M. B. H. S. (2014). Nahj al-Balagha: collection of sermons, letters and aphorisms of Imam Ali (AS). Ayati, Muhammad (Translation). Tehran: Office of Islamic Culture Publication.

Moein, M. (2004). Persian Dictionary (Vol. 1). Tehran: Saraee Publication.

\section{Copyrights}

Copyright for this article is retained by the author(s), with first publication rights granted to the journal.

This is an open-access article distributed under the terms and conditions of the Creative Commons Attribution license (http://creativecommons.org/licenses/by/4.0/). 